\title{
Sheep meat commercialization in the retail market in Brazilian cities
}

\author{
Ricardo Firetti ${ }^{1}$, Ana Lúcia Luz Alberti ${ }^{1}$, Marilice Zundt $^{2}$, Aline de Oliveira Santos ${ }^{2}$, Fabiola \\ Cristine de Almeida Rego ${ }^{3}$, José Luis de Lima Astolphi ${ }^{2}$
}

\footnotetext{
${ }^{1}$ Agência Paulista de Tecnologia dos Agronegócios, Presidente Prudente, SP, Brasil.

${ }^{2}$ Universidade do Oeste Paulista, Presidente Prudente, SP, Brasil.

${ }^{3}$ Universidade Norte do Paraná, Arapongas, PR, Brasil.
}

\begin{abstract}
This paper explored the mix market characteristics of sheep meat as a product for sale in different cities in the states of São Paulo and Paraná. For this, 81 products were purchased in 21 outlets sampled in a "non-probabilistic" manner for convenience and then subjected to analysis of yield of meat, bone, and fat. Imported products represented $20 \%$ of the total, being marketed in hypermarkets. It was observed that $37 \%$ of the total products were obtained in hypermarkets, $31 \%$ in supermarkets, $23 \%$ in butcher shops, and $8.6 \%$ in meat outlets. Almost $9 \%$ of the products had not undergone the official slaughter inspection system. The main types of products identified were palettes and legs with bones ( 33.3 and $24.7 \%$, respectively); however, only $25 \%$ were satisfactorily displayed to consumers. The yields obtained in meat and deboned portions were $74 \%$ and $59 \%$ of the total weight, significantly affecting the average adjusted sales prices of the products, respectively US\$13.01/ $\mathrm{kg}$ sale price; US\$17.82/ $\mathrm{kg}$ deboned; and US\$22.52/ $\mathrm{kg}$ lean meat. The low yield of clean and boned meat observed in the samples can lead to negative experiences of these products by consumers.
\end{abstract}

Key Words: lamb, marketing, multivariate analysis, sheep industry

\section{Introduction}

The commercialization of sheep meat in retail units is rapidly expanding, even with the reduction in the Brazilian herd estimated at 5\% between 2011 and 2013. The concentration in production is highlighted in the Northeast $(55.5 \%)$ and South (30\%), according to information from the "Municipal Livestock Production" survey conducted by the IBGE (2013). According to this Institute, the states of São Paulo and Paraná accounted, respectively, for 2.5 and $3.8 \%$ of the national herd.

It appears that the production growth possibilities are largely based on the increasing consumption of this meat due to its quality differential (flavor) and low fat, as well as its representation of an excellent source of protein. However, historically, appraisals of the Brazilian sheep industry have pointed to low coordination capacity of the production chain agents as one of the main obstacles to development of the sector (Braga and Rodrigues, 2005).

Received: November 9, 2016

Accepted: June 8, 2017

*Corresponding author: mari@unoeste.br

Copyright (C) 2018 Sociedade Brasileira de Zootecnia. This is an Open Access article distributed under the terms of the Creative Commons Attribution License (http://creativecommons.org/licenses/by/4.0/), which permits unrestricted use, distribution, and reproduction in any medium, provided the original work is properly cited.
Although established in the agroindustrial chain of beef cattle, market studies on sheep meat have recently been reported in the literature, with greater focus on the carcass characteristics and meat quality (Pinheiro et al., 2009; Esteves et al., 2010), sensory evaluation and acceptability to the consumer (Bonacina et al., 2011; Firetti et al., 2010, 2011; Pellegrin et al., 2012), with less focus on the recent retail supply of sheep meat in major Brazilian cities, especially São Paulo, and the characteristics of these products (Sorio et al., 2008; Reys et al., 2010).

Sorio et al. (2008), studying the supply of sheep meat in Campo Grande, MS, concluded that more than $60 \%$ of establishments offer this type of product and that illegal production was responsible for supplying meat to $22 \%$ of the establishments surveyed. The locations that sell meat derived from illegal production have prices between $13 \%$ and $15 \%$ lower than the same cuts sold in other establishments, leading to unfair retail competition.

The appearance of the final product offered is a factor to be considered according to Reys et al. (2010), who evaluated the importance of attributes to consumers buying sheep meat in Santa Maria, RS. This factor was considered a food quality indicator by consumers in this region, becoming the main factor in the product purchase decision, indicating that the price factor is no longer the main component in the decision to purchase the meat. 
Thus, the present work aimed to analyze these questions through exploratory research in cities in the states of São Paulo and northern Paraná, Brazil, to characterize the merchandising mix involving sheep meat for sale to consumers in the retail market, in terms of the product (cut offered, packaging, and origin), selling price to the consumer, point of sale (establishment and provision), and promotion within the retail unit.

\section{Material and Methods}

The research that originated this work is exploratory, which is necessary when there is little or superficial knowledge of the subject or object of the study, being, therefore, developed to provide a general overview of certain facts and/or when it is necessary to deepen preliminary concepts on a specific topic.

In total, 81 products were purchased in 21 retail units between September/2012 and June/2013 in the cities of Londrina and Maringá, located in the North of Paraná, and Presidente Prudente, Araçatuba, Marilia, Bauru, and São José do Rio Preto, located in the Central West region of São Paulo.

In view of sheep meat supply problems in retail in general, "non-probability" sampling was used for convenience (Malhotra, 2012), according to the availability of meat products at the points of sale (supermarkets, hypermarkets, butcher shops, and meat outlets). The criterion of three retail units per municipality was respected and one sample acquired of each sheep meat product available at the points of sale.

The product differentiation resulted from the variation among types of cut, the origin of the meat (city, state, or country), place of slaughter, product brand, physical state (frozen or unfrozen), and type of packaging (vacuum or the presence of air).

After acquisition, the meat was stored in insulated boxes and transported for analysis in Presidente Prudente, SP. The products were thawed in the refrigerator (in their original packaging) at $10{ }^{\circ} \mathrm{C}$ for 20 to $40 \mathrm{~h}$, depending on the size of the pieces, according to the methodology provided by Pinheiro et al. (2009). The bone, muscle, fat, and other inedible parts were separated from the original cuts to determine the weight $(\mathrm{kg})$. The consumer price was collected at the points of sale and the values reported on the product weight labels, receipts, or tax receipts were used. The evaluation of the point of sale was performed through the descriptive characterization of these items and a subjective score using a 3-point scale (1 - unsatisfactory; 2 - partially satisfactory; 3 - satisfactory).
Thus, the original data allowed the elaboration of the following variables: Variable $1=$ total frozen weight $(\mathrm{kg})$; Variable 2 = total unfrozen weight $(\mathrm{kg})$; Variable $3=$ bone weight $(\mathrm{kg})$; Variable $4=$ muscle weight $(\mathrm{kg})$; Variable $5=$ meat percentage $(\%)$; Variable $6=$ bone percentage $(\%)$; Variable $7=$ fat percentage $(\%)$; Variable $8=$ weight of deboned product $(\mathrm{kg})$; Variable $9=$ relative weight of deboned product $(\%)$; Variable $10=$ sale price $(\mathrm{US} \$ / \mathrm{kg})$; Variable $11=$ price of clean meat $(\mathrm{R} \$ / \mathrm{kg})$; Variable $12=$ price of deboned product $(\mathrm{R} \$ / \mathrm{kg})$; Variable $13=$ city of sale; Variable $14=$ type of retail establishment; Variable $15=$ state of origin of slaughter; Variable $16=$ country of origin of slaughter; Variable $17=$ inspection type in the slaughter (absent, municipal, state, federal); Variable 18 = product type (palette with bone, shank with bone, rib, loin, steaks, boned cuts); Variable 19 = presence of logo (yes, no); Variable $20=$ product display in retail outlet (cold room, with other meats, exclusive display); Variable $21=$ evaluation of point of sale; Variable 22 = percentage boneless yield (\%).

The results were tabulated and evaluated through distribution analysis of classes of relative frequencies (Gil, 2012; Pereira, 2004) and multivariate techniques (Hair et al., 2009) such as factor analysis, multiple correlation $(\mathrm{P}>0.05)$, and correspondence analysis, using Statistica software (version 8.0).

The first step during the implementation of the multivariate techniques was to utilize the Crombach Alpha Test that measures the reliability of the collected instruments from the correlation between responses. The variables that interfered negatively in the total value of the index were excluded from the analysis (Hair et al., 2009).

The second step was to observe if the data matrix could be subjected to the factor analysis process. For this, two methods of evaluation were used: the Kaiser-Meyer-Olkin (KMO) criterion for the measure of sampling adequacy (MSA) and Bartlett's Sphericity test (Hair et al., 2009).

In the factor analysis, the "method of principal components" was utilized and the initial data were subjected to orthogonal factor rotation (varimax raw) with the identification of the number of factors extracted performed with the latent root criterion (factors having an eigenvalue above 1.0). Factorial loads above 0.6 were identified, indicating statistically valid commonalities for the identification of these variables present in each factor.

In correspondence analysis, the objective is to trace associations between the variables that compose the study, expanding the explanatory capacity of the sample (Hair et al., 2009). Necessarily, the variables with higher commonalities in the factors are used, together with others pertaining preferentially to the same factor. In some cases, 
variables of different factors may be used, provided that their commonality is above 0.4. Therefore, the results obtained in the quantitative variables were transformed into classes of 1 to 4 points using relative frequencies.

\section{Results}

Around $23.4 \%$ of the 81 products examined were obtained in Presidente Prudente, 19.7\% in Marília, 16\% in Londrina, and $11.1 \%$ in Maringá. The cities of Bauru, Araçatuba, and São José do Rio Preto presented the same percentage values $(9.8 \%)$. These values represent the geographical distribution of the range of products available for sale on the shelves of the retail units observed. However, they are not necessarily related to higher or lower consumption of sheep meat.

With respect to the retail establishments, it was observed that $37 \%$ of the total products were obtained in hypermarkets, $30.8 \%$ in supermarkets, $23.4 \%$ in butcher shops, and $8.6 \%$ in meat outlets. The percentage of products found in butcher shops draws attention in view of the fact that the specialized literature mentions difficulties in the supply and availability of sheep meat in general.

The main observed origin of sheep meat was the state of São Paulo (39.5\%), followed by Rio Grande do Sul (22.2\%), Uruguayan states (14.8\%), Bahia (9.8\%), Paraná (8.6\%), and Argentinian states (4.9\%). Thus, imported products accounted for nearly $1 / 5$ of the total available in the analyzed retailers, absorbing a significant portion of the consumer market in these regions.

It is noteworthy that $8.6 \%$ of the products purchased did not pass through the Brazilian municipal, state, or federal slaughter inspection system. The Federal Inspection System (FIS) was present in $61.7 \%$ of the products and state systems in $11.1 \%$. It is worth noticing that $18.5 \%$ of the products were imported and, therefore, under the standards of inspection of their home countries.

With regard to the products, six different "classes" or types of products were identified: palette with bone $(33.3 \%)$, leg with bone $(24.7 \%)$, leg and/or palette steaks $(13.6 \%)$, rib sections (11.1\%), rack (11.1\%), and boneless cuts $(6.17 \%)$ such as sirloin, rump, and sheep flank steak. Only $23.4 \%$ of the products were not vacuum-packed, all of which were acquired in butcher shops. Approximately $54 \%$ of the products had logos with sophisticated names, aiming at some kind of differentiation, which amounted to a valuation on the basis of "brand" of the meat.

Around $60 \%$ of the products analyzed were available in this way, while $23.4 \%$ were placed in separate freezers, and $17.2 \%$ were stored in cold rooms (butcher shops).
Subjective analysis of points of sale (shelves and freezers) demonstrated that only $24.7 \%$ of the products were packaged for sale in a satisfactory condition, while $44.4 \%$ were in an unsatisfying condition, impeding or negatively influencing the sale of the products.

In the studied correlation analysis, the main indices found $(\mathrm{P}<0.05)$ were between the variables "Type of retail establishment" and "Product display in retail outlet" $(0.71)$ with "Inspection type in the slaughter" (0.61).

The retail sales prices (US\$ $/ \mathrm{kg}$ ) ranged from US\$ 4.34 (neck steak) to US\$ 33.25 (t-bone steak), with an overall average of US\$ $13.01 / \mathrm{kg}$ (Table 1). Contrary to expectations, different boneless cuts were found with retail prices ranging from US\$13.84/kg (skirt steak) to US\$30.58/kg (rump steak).

Concerning the meat yield after boning and separation of the lean meat portion, i.e., only muscle without fat (Table 1), the average percentages found were 73.9 and $58.7 \%$ respectively. The analyzed meat cuts had about $15 \%$ fat (mean).

Thus, taking into account the subtraction of bone weights (deboned product) for "correction" of sales prices, the values obtained were US\$17.83/ $\mathrm{kg}$ (mean), US\$6.82/kg (minimum), and US\$ $42.68 / \mathrm{kg}$ (maximum), the minimum price for the rib and the maximum for the t-bone steak. The "corrected" sale prices for the lean meat portion was US\$ $22.52 / \mathrm{kg}$ (mean), US\$ 8.40/kg (minimum), and US\$ 52.96/kg (maximum).

To perform the multivariate analysis, a set of variables was selected, which presented an acceptable degree of internal consistency, using the criteria described in the literature (Hair et al., 2009) for Cronbach's Alpha. In this way, of 22 original variables, 14 were obtained having a coefficient of 0.70 .

Table 1 - Mean, minimum, maximum, and standard deviation (SD) values of quantitative variables of the purchased meat samples

\begin{tabular}{lcccc}
\hline & Mean & Minimun & Maximum & SD \\
\hline Defrosted weight (kg) & 1.5 & 0.3 & 3.5 & 0.7 \\
Bone weight (kg) & 0.3 & 0.0 & 0.7 & 0.1 \\
Muscle weight (kg) & 0.9 & 0.2 & 2.3 & 0.5 \\
Fat weight (kg) & 0.2 & 0.0 & 0.8 & 0.2 \\
Percentage of meat (\%) & 58.7 & 33.9 & 91.2 & 11.6 \\
Percentage of bone (\%) & 17.7 & 0.0 & 29.6 & 6.8 \\
Percentage of fat (\%) & 15.2 & 1.6 & 41.4 & 8.9 \\
Deboned weight (kg) & 1.1 & 0.3 & 2.7 & 0.6 \\
Deboned percentage (\%) & 73.9 & 52.6 & 96.8 & 9.1 \\
Sale price (US\$/kg) & 13.0 & 4.3 & 33.2 & 10.7 \\
Meat price (US\$ $/ \mathrm{kg})$ & 22.5 & 8.4 & 52.9 & 17.5 \\
Deboned price $(\mathrm{US} \$ / \mathrm{kg})$ & 17.8 & 6.8 & 42.6 & 14.8 \\
\hline
\end{tabular}


Subsequently, the 14 variables were subjected to the MSA, resulting in 0.60. According to Hair et al. (2009), the MSA should be above 0.5 .

Bartlett's sphericity test presented a significant result $(\mathrm{P}<2.22 \mathrm{e}-16)$, with value equal to $3,729.861$. This result confirms the existence of a correlation between the variables.

In the factorial analysis (principal components method), four cumulative factors were extracted to explain $75.8 \%$ of the total sample variance (Table 2). In the extraction of the factors, eigenvalues greater than 1.0 were considered. The factorial multivariate method was applied to guide the correspondence analysis, in view of its ability to "reduce" a large number of variables into a smaller number of factors in which the original variables are correlated and will be represented.

According to Fuentes Llanillo et al. (2006), commonality is a measure of the quality of explanation of a variable and assumes values from 0 to 1 , being considered high when 0.7 to 1 , average when 0.5 to 0.69 , and low when less than 0.50 (Table 3). However, for Hair et al. (2009), using average commonalities is totally acceptable when using the technique with an exploratory objective.

In the correspondence analysis, quantitative values of the variables "Retail price (US\$/kg)" and "Deboned price (US\$/kg)" were transformed and organized into four classes,

Table 2 - Explained variance to factors and accumulated variance

\begin{tabular}{lcccc}
\hline & Eigenvalue & \% total variance & $\begin{array}{c}\text { Cumulative } \\
\text { eigenvalue }\end{array}$ & Cumulative \% \\
\hline Factor 1 & 5.09 & 33.91 & 5.09 & 33.91 \\
Factor 2 & 3.20 & 21.36 & 8.29 & 55.26 \\
Factor 3 & 1.67 & 11.10 & 9.95 & 66.37 \\
Factor 4 & 1.43 & 9.50 & 11.38 & 75.87 \\
\hline
\end{tabular}

Table 3 - Commonalities between the variables analyzed and extracted factors

\begin{tabular}{lcrrr}
\hline & Factor 1 & Factor 2 & Factor 3 & Factor 4 \\
\hline Bone weight $(\mathrm{kg})$ & -0.46 & 0.18 & 0.16 & -0.61 \\
Muscle weight $(\mathrm{kg})$ & -0.25 & 0.15 & 0.07 & -0.86 \\
Fat weight $(\mathrm{kg})$ & -0.14 & -0.35 & 0.13 & -0.72 \\
Deboned weight $(\mathrm{kg})$ & -0.25 & 0.00 & 0.10 & -0.94 \\
Sale price (US\$ $/ \mathrm{kg})$ & 0.91 & 0.18 & -0.17 & 0.18 \\
Meat price (US $\$ \mathrm{~kg})$ & 0.89 & 0.06 & -0.02 & 0.20 \\
Deboned price (US\$ $/ \mathrm{kg})$ & 0.87 & 0.22 & -0.11 & 0.27 \\
Type of retail establishment & 0.25 & -0.34 & -0.82 & 0.14 \\
State of origin & 0.21 & 0.90 & 0.14 & 0.09 \\
Country of origin & 0.12 & 0.89 & 0.01 & -0.08 \\
Inspection type in the slaughter & -0.15 & -0.63 & -0.54 & 0.20 \\
Presence of logo & -0.06 & 0.38 & -0.78 & 0.29 \\
Evaluation of point of sale & 0.13 & -0.25 & -0.78 & -0.08 \\
Type of product & 0.65 & 0.01 & 0.31 & 0.20 \\
\hline
\end{tabular}

increasing, due to the relative frequency of observations, to facilitate interpretation of the results shown in the graphs, as indicated by Hair et al. (2009).

Thus, in the correspondence analysis between the variables "Sale price" (0.91) and "Product type" (0.65), both correlated to Factor 1 (Figure 1), it is possible to see four groups formed by the classes of sale price and types of products found in the shops. The ribs corresponded to the lowest sale price class (1), while the loin (3) and boneless cuts (4) were more related to the higher prices. Both the leg and palette with bone presented correspondence with the classes of initial values (1 and 2), indicating great variability in the price of these types of products. "Steak" was not inserted to a specific group, yet its price variation was among the highest classes (4 and 5).

However, when we analyzed the variables "Deboned price" (0.87) and "Product type" (0.65), also present in Factor 1, new groups were established in a different conformation to a previously analyzed (Figure 2). The rib and shank products with bone were associated with lower prices charged. Deboned products, steaks, and loin corresponded, respectively, with the price classes 2, 3, and 4 . The palette with bone, in turn, appeared to present a tendency of association with the lowest price classes (1 and 2).

Moving on to factor 3, from the correspondence analysis between the variables "Type of retail establishment" $(0.82)$ and "Evaluation of point of sale" $(-0.78)$, it is possible to observe the formation of three groups, with the points of

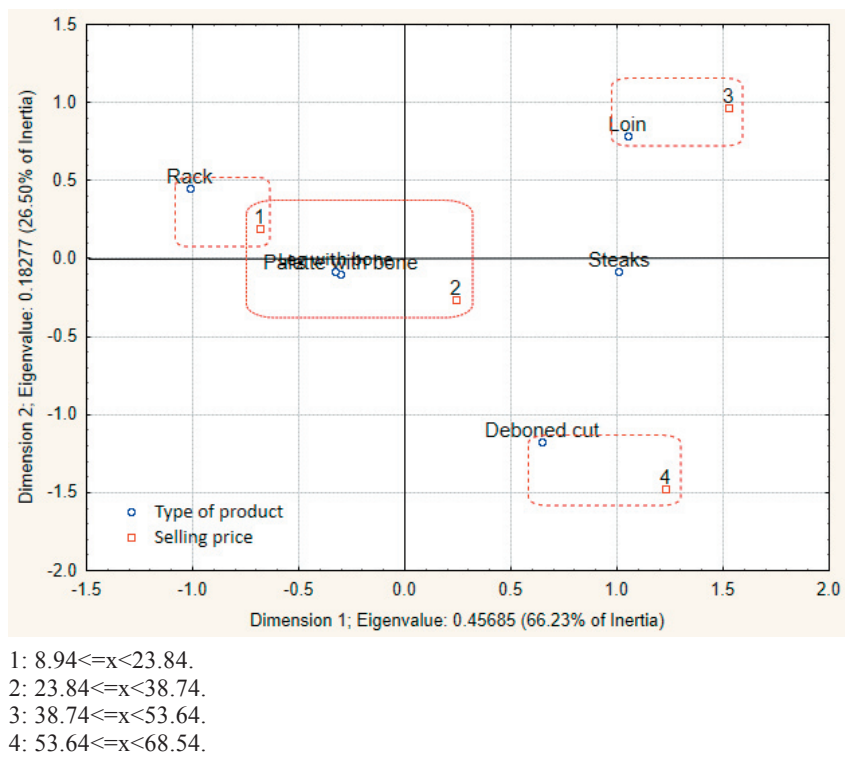

Figure 1 - Correspondence analysis between the variables "Product type" and "Sale price" (US\$/kg). 
sale evaluated as "unsatisfactory" for the meat markets and the best evaluation for meat outlets (Figure 3).

The analysis of the variables "Type of retail establishment", belonging to factor 3, and "Inspection type in the slaughter", which had a commonality of 0.54 in Factor 3, although belonging to Factor 2, clearly shows the high correlation between the meat markets and the lack of sanitary inspection in the slaughter of the animals, which gave rise to the meat sold in these establishments (Figure 4).

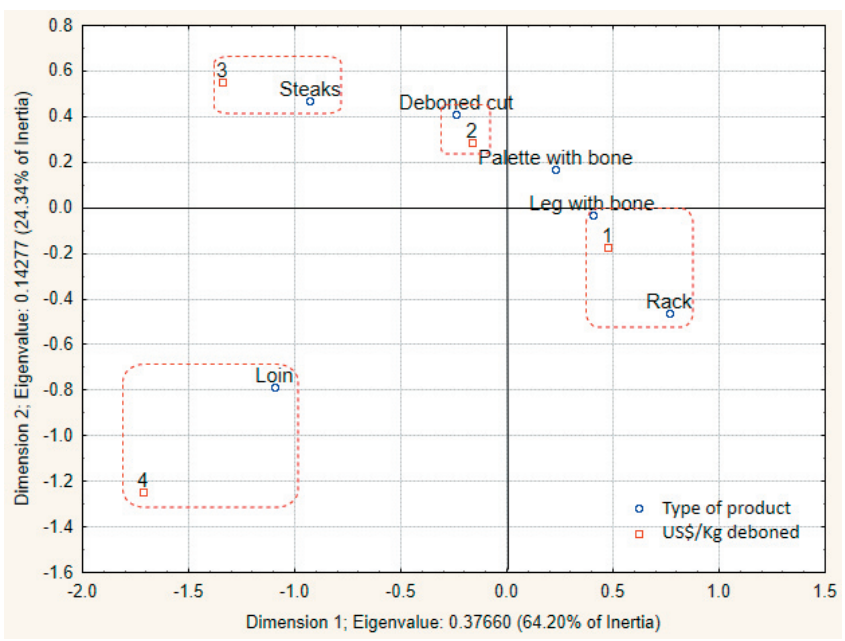

1: $14.04<=\mathrm{x}<33.04$.

2: $33.04<=\mathrm{x}<52.04$

3: $52.04<=\mathrm{x}<71.04$

4: $71.04<=\mathrm{x}<90.04$

Figure 2 - Correspondence analysis between the variables "Product type" and "Boneless price" (US\$ $/ \mathrm{kg}$ ).

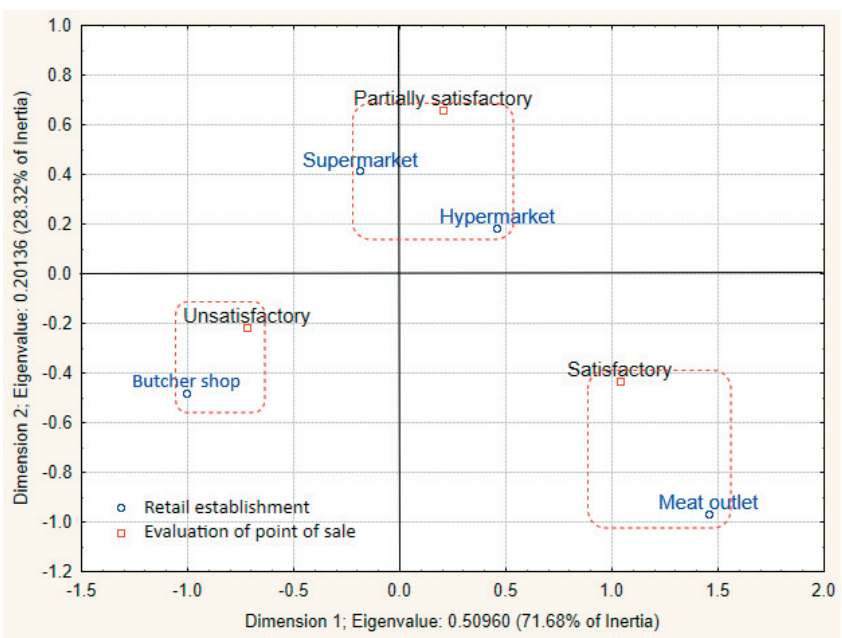

Figure 3 - Correspondence analysis between the variables "Type of retail establishment" and "Evaluation of point of sale".

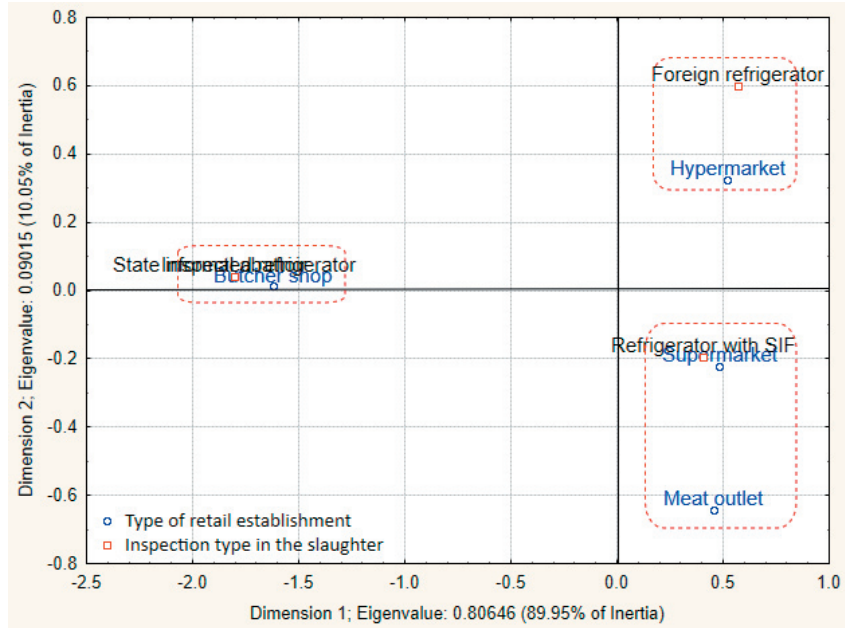

Figure 4 - Correspondence analysis between the variables "Type of retail establishment" and "Inspection type in the slaughter".

\section{Discussion}

The magnitude of the variation in retail sale prices for sheep meat found in this study is similar to that observed in the work of Sorio et al. (2008) and highlights the difficulty consumers have to form a concept of what is a fair price to pay for sheep meat.

Groupings in the correspondence analysis consolidated the segmentation of the sheep meat retail market, since they point to the formation of different groups on the basis of the official inspection system, involving mainly supermarkets (local coverage) and meat outlets, and the presence of products inspected in other countries being marketed in large hypermarket networks.

The absence of sanitary inspection at slaughter of the meat sold in butcher shops corroborates that seen in other work regarding the informality in agribusiness systems and the sheep meat market in the city of Maringá, PR (Bánkuti et al. 2013), in which $34 \%$ of respondents stated that they purchased products from animals slaughtered without official health inspection due to a mix of better pricing, availability, and "Guarantee of origin".

Firetti et al. (2011; 2010) observed in surveys with consumers that between 25 and $30 \%$ of individuals surveyed preferred to buy meat directly from farmers without any inspection of the slaughtering procedures by regulators.

Ramos et al. (2014), evaluating the agroindustrial system of sheep meat in west Paraná, found that the sheep industry rests on an unstable and highly competitive environment, with the most influential, and at the same time highly dependent, variable being clandestine slaughter. 
Corroborating this information, Sorio (2013) described that informality is present in the entire urban area of Brazil, once, in meat without inspection, consumers see a "legitimate free-range product", which brings sentimental attachment to the farm and memories of a past age, often having no concern with the hygiene and health aspects related to the production of food of animal origin.

Sorio et al. (2008), studying the supply of sheep meat in Campo Grande, MS, concluded that more than $60 \%$ of establishments offered this type of product and clandestine slaughter was responsible for supplying meat to $22 \%$ of the establishments surveyed.

As for the placement of sheep meat for sale to the consumer and forms of display of the products, what stood out was the fact that supermarkets and hypermarkets were grouped in the intermediate level of qualitative evaluation (partly satisfactory), denoting a certain lack of concern with the form and quality of availability of sheep meat products to consumers, negatively influencing their marketing.

The availability of sheep meat in the analyzed retail units (points of sale) is directly related to its importance in the total sales. In general, in hypermarkets and supermarkets, it is considered "exotic meat" and is placed in vertical freezers with ducks, mallards, rabbits, pigs (shank, ribs), or beef with high added value (differentiated).

These facts can be explained by the hypothesis that the production chain in the sheep industry is undergoing a transition to a "modernized activity", dependent on the supply of inputs, but without establishing specific links "before and after the farm gate"; this leads to an incomplete agroindustrial complex in which there is some connection with the downstream sector (after the farm gate), according to the classification methodology described by Farina and Zylbersztajn (1991).

\section{Conclusions}

There is a varied supply of products in different types of retail establishments in the analyzed cities. A part of the meat offered in butcher shops comes from slaughter without official inspection, which indicates problems in the supply chain.

The main negative aspect identified is the low yield of clean and boned meat observed in the samples, which can lead to negative experiences of these products by consumers and difficulties in consolidating and increasing demand.

\section{Acknowledgments}

We acknowledge the Fundação de Amparo à Pesquisa do Estado de São Paulo (FAPESP), for the financial support to carry out this research.

\section{References}

Bánkuti, F. I.; Bánkuti, S. M. S. and Macedo, F. A. 2013. A informalidade em sistemas agroindustriais: um estudo exploratório dos hábitos de consumo de carne ovina na cidade de Maringá, Estado do Paraná. Informações Econômicas 43:5-17.

Bonacina, M. S.; Osório, M. T. M.; Osório, J. C. S.; Correa, G. F. and Hashimoto, J. H. 2011. Influência do sexo e do sistema de terminação de cordeiros Texel $\times$ Corriedale na qualidade da carcaça e da carne. Revista Brasileira de Zootecnia 40:1242-1249.

Braga, M. and Rodrigues, M. T. 2005. Diagnóstico da cadeia produtiva da ovinocaprinocultura no Estado de Alagoas. Sebrae, Maceió.

Esteves, R. M.; Osório, J. C. S.; Osório, M. T. M.; Mendonça, G.; Oliveira, M. M.; Wiegand, M.; Vilanova, M. S.; Correa, F. and Jardim, R. D. 2010. Avaliação in vivo e da carcaça e fatores determinantes para o entendimento da cadeia da carne ovina. Revista Brasileira de Agrociência 16:101-108.

Farina, E. Q. and Zylbersztajn, D. 1991. Relações tecnológicas e organização dos mercados do sistema agroindustrial de alimentos. Cadernos de Ciência \& Tecnologia 8:9-27.

Firetti, R.; Carrer, C. C.; Silva, V. L. S.; Trindade, M. A.; Souza, S. C.; Savastano Junior, H. and Ribeiro, M. M. L. O. 2010. Percepção de consumidores paulistas em relação à carne ovina: análise fatorial por componentes principais. Revista Brasileira de Saúde e Produção Animal 11:1-13.

Firetti, R.; Costa, L. P. R.; Moreira, A. L.; Carrer, C. C. and Ribeiro, M. M. L. O. 2011. Aspectos mercadológicos da carne ovina no município de Presidente Prudente, Estado de São Paulo. Informações Econômicas 41:5-18.

Fuentes Llanillo, R.; Del Grossi, M. E.; Santos, F. O.; Munhos, P. D. and Guimarães, M. F. 2006. Regionalização da agricultura do Estado do Paraná, Brasil. Ciência Rural 36:120-127.

Gil, A. 2012. Método e técnicas de pesquisa social. 6.ed. Atlas, São Paulo.

Hair, Jr., J. F.; Black, W. C.; Babin, B. J.; Anderson, R. E. and Tatham, R. L. 2009. Análise multivariada de dados. Tradução: Adonai Schlup Sant'Anna. 6.ed. Bookman, Porto Alegre.

IBGE - Instituto Brasileiro de Geografia e Estatística. 2013. Produção da Pecuária Municipal 2013. IBGE, Rio de Janeiro. Available at: $<\mathrm{ftp}$ //ftp.ibge.gov.br/Producao_Pecuaria/Producao_da_Pecuaria_ Municipal/2013/ppm2013.pdf > . Accessed on: May, 28, 2016.

Malhotra, N. K. 2012. Pesquisa de marketing: uma orientação aplicada. Bookman, Porto Alegre.

Pellegrin, A. C. R. S.; Pires, C. C.; Nalério, E. S.; Wommer, T. P. and Lopes, J. F. 2012. Análise sensorial mediante teste triangular da carne de cordeiros lactentes mantidos a pasto suplementados no creep-feeding sem ou com glicerina bruta. Synergismus scyentifica 7(1).

Pereira, J. C. R. 2004. Análise de dados qualitativos: estratégias metodológicas para as ciências da saúde, humanas e sociais. 3.ed. EDUSP, FAPESP, São Paulo.

Pinheiro, R. S. B.; Silva Sobrinho, A. M.; Hirasilva, B. A. S. and Yamamoto, S. M. 2009. Qualidade de carnes provenientes de cortes 
da carcaça de cordeiros e de ovinos adultos. Revista Brasileira de Zootecnia 38:1790-1796.

Ramos, M.; Rocha Junior, W.; Schmidt, C. and Fagundes, M. 2014. Sistema agroindustrial da carne ovina no Oeste paranaense. Revista de Política Agrícola 23:18-32.

Reys, M. A.; Silveira, V. C. P.; Viana, J. G. A.; Gabriel, C. C. and Barchet, I. 2010. Atributos de importância na compra de carne ovina pelos consumidores de Santa Maria - RS. Revista em Agronegócio e Meio Ambiente 3:31-40.

Sorio, A. 2013. A carne ovina e o abate clandestino: a informalidade tem jeito? Revista Cabra \& Ovelha 78:6-7.

Sorio, A.; Fagundes, M. B. B. and Leite, L. R. C. 2008. Oferta de carne ovina no varejo de Campo Grande (MS): uma abordagem de marketing. Revista Agrarian 1:145-156. 